inOedia $\quad \begin{aligned} & \text { InMedia } \\ & \text { The French Journal of Media Studies }\end{aligned}$

$1 \mid 2012$

Global Film and Television Industries Today

Linda Gordon, Dorothea Lange: A Life Beyond Limits

New York: W.W. Norton, 2009, 536 pages

Hélène Quanquin

(2) OpenEdition

Journals

Electronic version

URL: http://journals.openedition.org/inmedia/151

DOI: 10.4000/inmedia.151

ISSN: 2259-4728

Publisher

Center for Research on the English-Speaking World (CREW)

Electronic reference

Hélène Quanquin, «Linda Gordon, Dorothea Lange: A Life Beyond Limits », InMedia [Online], 1 | 2012,

Online since 16 March 2012, connection on 10 December 2020. URL : http://journals.openedition.org/ inmedia/151; DOI : https://doi.org/10.4000/inmedia.151

This text was automatically generated on 10 December 2020 .

(c) InMedia 


\section{Linda Gordon, Dorothea Lange: A Life Beyond Limits}

New York: W.W. Norton, 2009, 536 pages

Hélène Quanquin

\section{REFERENCES}

Linda Gordon, Dorothea Lange: A Life Beyond Limits, New York: W.W. Norton, 2009, 536 pages

1 In June 2007, the Schlesinger Library at the Radcliffe Institute for Advanced Study at Harvard University organized its first summer seminar on "Writing Past Lives: Biography as History," which sought to investigate "how a focus on individual lives can further historical analysis." One of the plenary speakers was Linda Gordon, who was invited to speak on her work on the biography of American documentary photographer Dorothea Lange. The first picture which she showed was neither "Migrant Mother" (1936) nor "White Angel Breadline" (1932), nor was it part of Lange's most famous work in Depression-stricken rural America conducted for the Farm Security Administration from 1935 to 1939. Instead, Gordon chose a picture probably no one in the audience had ever seen, that of Lange's polio-twisted foot, the closest to a self-portrait she ever came to. In the second half of the 1950s, when Lange was teaching photography at the California School of Fine Arts in San Francisco, she gave her students an assignment which was to produce photographs in answer to the question "Where do I live?" Lange's picture of her foot was her own version of this assignment and for Gordon, "[t]his is where she lived, she felt-imprisoned in this imperfect body" (p. 3).

2 The story told by Gordon sent a chill through the audience at the Schlesinger Library, but her choice to open both her lecture and her book with it is significant of her difficulty in writing the biography of a woman like Dorothea Lange, whose skill and art relied on her ability to become as invisible as possible, a woman on the move, who, with a few exceptions, did not document her life. Gordon's approach to Lange and to 
biography itself is shaped by the fact that she is neither a practised photography specialist nor a biographer, but a historian of national policy issues - she is a Professor of History at New York University. The project also did not originate with her, but with another biographer, whose work she picked up after he died prematurely. For Gordon, making this project her own meant to try and connect her own practice as an historian with Lange and her work. In the introduction, she draws a potent parallel between history as she sees it and "documentary," whose goal is "revealing the truth and promoting social justice" (p. xvi). Throughout Dorothea Lange, Gordon chose to make her voice heard and her challenges as a biographer visible to the reader.

Dorothea Lange was born on May 26, 1895, in Hoboken, New Jersey. Her parents were well-to-do German Americans who valued culture and education. Lange experienced two "childhood traumas" (p. 4), which Gordon sees as crucial although they were never articulated as such by Lange: when she was seven, she was struck by polio, which left her with a distorted leg; five years later, her parents separated and she hardly ever saw her father again, accusing him of deserting his family, although it is more likely that he fled charges of embezzlement. Still living in Hoboken, Lange's mother took a job in New York City, where Lange attended school and was frequently left by herself. Gordon makes of these years spent walking the streets of the big city Lange's formative years, during which "she learned to see" (p. 24). A poor student, she dropped out of school and, in 1912 or 1913, was hired as an assistant by famous German-American photographer Arnold Genthe, who trained her, and eventually worked for seven other photographers. In 1918, Lange set out with a friend of hers on a trip around the world, which ended with their arrival in San Francisco. This was where she married her first husband, painter Maynard Dixon, and started her first career as a successful portrait photographer for the wealthy and the flourishing artists' community there.

It is to Gordon's credit that she managed to establish a sense of continuity between Lange's seemingly very different, and sometimes lesser known and valued, phases in her work as a photographer. Lange's most famous work was made between 1935 and 1945, photographing for various government administrations-documenting the effects of the Depression in the rural areas of the West and South of the United States for the Farm Security Administration, headed by Roy Stricker, then the internment of Japanese Americans for the War Department, and working for different projects for the Office of War Information during World War II. ${ }^{1}$ Gordon's premise that historical evidence is to be found in Lange's photographs more than in her words accounts for her choice to widen the scope of her analysis beyond Lange's most famous body of work, articulating it with the portraits taken by Lange at the beginning of her commercial career in San Francisco as well as with the photographs she produced later in life in a series of trips outside of the United States-in Ireland in 1954, and in Asia and the Middle East between 1958 and 1962. For her biographer, Lange was "a photographer of democracy and for democracy" (p. xiii), whatever the subjects of her pictures. The commercial photography she engaged in early on helped her perfect the "powerful documentary technique" (p. 64) which she used in the more committed work she produced in the 1930s as a dialogue with her second husband, Paul Taylor, a left-wing economist and expert in agricultural reform. Lange's goal was "to show people in their contexts" (p. 213), as individuals.

5 Gordon's decision to show her subject as a woman "shaped by experience both individual and historical" (p. 425) echoes Lange's own project. Although her 
photographs show sensitivity to the plight of women, Lange was not a feminist. But Lange was a pioneer, in the sense that she lived a life no woman had lived before her. The pages on Lange's family life and her difficult relationships with her two sons and her stepchildren are significant, insofar as they help the reader explore the complexities of Lange's choices as a woman in the face of unusual constraints and her relation to her craft. Because of the lack of reliable sources and because of Gordon's caution toward what she saw as the possibly tainted testimonies of Lange's relatives, however, this biography is more convincing in its analysis of Lange's photographic experience and legacy than in the pages devoted to her personal life and the way it might have interacted with her art.

\section{NOTES}

1. In 2008, Linda Gordon and Gary Okihiro published a selection of 119 of Lange's never published photographs of the internment of Japanese Americans. See Impounded: Dorothea Lange and Japanese Americans in World War II (New York: W.W. Norton \& Company, 2008).

\section{AUTHORS}

\section{HÉLÈNE QUANQUIN}

Université Sorbonne Nouvelle - Paris 3 